\title{
FAKTOR - FAKTOR YANG BERPENGARUH TERHADAP INDEKS HARGA SAHAM GABUNGAN PADA BURSA EFEK INDONESIA
}

\author{
Yohandes Rabiqy \\ biqy85@gmail.com \\ Universitas Teuku Umar
}

\begin{abstract}
The purpose of this study was to determine the effect of the inflation, IBCinterest rate, and exchange rate on CSPI. The research was conducted on the Indonesia Stock Exchange (ISE) by using sample of 72 consisted of the entire variable monthly data during 2010 to 2015 with the selection of the sample through a non probability sampling method by purposive sampling method and the data were analyzed with multiple linear regression analysis techniques. Based on the analysis found inflation, IBC interest rates, and exchange rates simultaneously affect the CSPI. The Inflation and IBC interest rates partially significant negative effect on the CSPI, this means an increase in inflation and $I B C$ interest rates may result decrease value of CSPI. Exchange rates partially significant positive effect on CSPI. This means that the increase occurred in exchange rates can increase the value of CSPI.
\end{abstract}

Kata kunci: Inflasi, Suku Bunga, Kurs, Indeks Harga Saham Gabungan (IHSG)

\section{Pendahuluan}

Pada tahun 2008 terjadi krisis keuangan dunia yang ditandai dengan kebangkrutan beberapa perusahaan besar di Amerika Serikat, hal ini terjadi karena dipicu krisis kredit perumahan, produk sekuritas. Krisis ini ikut memengaruhi perekonomian Indonesia, salah satu indikatornya yaitu jatuhnya harga saham di pasar modal. Indeks Harga Saham Gabungan (IHSG) merupakan cerminan dari kegiatan pasar modal secara umum. Peningkatan IHSG menunjukkan pasar modal sedang bullish, sebaliknya jika menurun menunjukkan kondisi pasar modal sedang bearish. Untuk itu, seorang investor harus memahami pola perilaku harga saham di pasar modal.

Analisis ekonomi memiliki integrasi yang sangat kuat terhadap keadaan pasar modal (Kudal, 2010). Menurut para pakar ekonomi, kinerja suatu pasar modal mempunyai hubungan yang kuat dengan lingkungan ekonomi makro. Ada beberapa faktor atau variabel ekonomi yang dapat memengaruhi harga saham antara lain pertumbuhan GDP, produksi industri, inflasi, tingkat suku bunga, nilai tukar rupiah, pengangguran dan anggaran defisit (Sunariyah, 2006). Tandelilin (2010) menyatakan bahwa faktor-faktor makro ekonomi secara empiris telah terbukti mempunyai pangaruh terhadap kondisi pasar modal di beberapa negara.

Suku bunga merupakan faktor penting dalam perekonomian suatu negara karena suku bunga mampu memengaruhi perekonomian secara umum. Tingkat suku bunga mempunyai pengaruh yang sangat kuat terhadap pasar modal (Manurung, 2009). Suku bunga Sertifikat Bank Indonesia (SBI) merupakan instrumen keuangan yang diterbitkan Bank Indonesia (BI) untuk mengontrol peredaran uang di masyarakat dengan menggunakan acuan suku bunga SBI, 
(Rismawati, 2013). Suku bunga SBI merupakan tingkat suku bunga yang ditetapkan oleh BI sebagai patokan bagi suku bunga pinjaman maupun simpanan bagi bank dan atau lembaga-lembaga keuangan di seluruh Indonesia. Suku bunga merupakan salah satu variabel yang dapat memengaruhi harga saham. Perubahan tingkat suku bunga selanjutnya akan memengaruhi keinginan seseorang untuk melakukan suatu investasi, karena secara umum perubahan suku bunga SBI dapat memengaruhi suku bunga deposito dan suku bunga kredit di masyarakat, (Amin,

2012). Jika Suku bunga deposito meningkat maka investor cenderung menanamkan modalnya dalam bentuk deposito karena dapat menghasilkan return yang besar dengan resiko yang lebih kecil dan sebaliknya. Dalam penelitian ini suku bunga SBI menggunakan data suku bunga SBI bulanan yang dipublikasikan oleh Bank Indonesia.

Inflasi merupakan kecenderungan harga naik secara terus menerus atau dapat diartikan sebagai penurunan nilai uang secara menyeluruh, makin tinggi kenaikan harga makin turun nilai uang. Inflasi yang sangat tinggi dapat mengganggu perekonomian secara umum karena selain dapat menurunkan daya beli karena penurunan nilai mata uang juga dapat meningkatkan resiko penurunan pendapatan riil masyarakat. Dalam investasi, inflasi yang tinggi mengakibatkan investor lebih berhati-hati dalam memilih dan melakukan transaksinya, sehingga investor cenderung menunggu untuk berinvestasi sampai keadaan perekonomian kondusif untuk menghindari resiko-resiko yang mungkin ditimbulkan oleh inflasi yang tinggi. Dalam penelitian ini menggunakan data inflasi berdasarkan consumer price indeks. Indeks ini berdasarkan pada harga dari satu paket barang yang dipilih dan mewakili pola pengeluaran konsumen (Raharjo, 2010).

Indeks Harga Saham Gabungan (IHSG) menggambarkan suatu rangkaian informasi historis mengenai pergerakan harga saham gabungan, sampai pada tanggal tertentu. Biasanya pergerakan harga saham tersebut disajikan setiap hari berdasarkan harga penutupan di bursa efek pada hari tersebut. IHSG merupakan cerminan kinerja saham-saham seluruh perusahaan yang terdaftar di Bursa Efek Indonesia (BEI), (Sunariyah, 2006).

Dalam penelitian ini menggunakan data Indeks Harga Saham Gabungan (IHSG) karena IHSG adalah salah satu indeks harga saham di BEI yang juga digunakan sebagai indikator perekonomian Indonesia di pasar modal. Periode penelitian yang dilakukan selama 6 tahun yaitu dari tahun 2010 sampai dengan tahun 2015 yang merupakan periode setelah terjadinya krisis global yang melanda seluruh dunia termasuk Indonesia.

Penelitian ini akan mengkaji pengaruh inflasi, suku bunga, dan kurs terhadap Indeks Harga Saham Gabungan pada Bursa Efek Indonesia.Berkaitan dengan hal tersebut, berikut ini ditampilkan tabel yang berisi data IHSG antara tahun 2010 sampai dengan tahun 2015. 
Tabel 1.I Perkembanuau Iudeks Haiga Saloam Gahnugau Tahun 2010-2015

\begin{tabular}{|c|c|c|}
\hline Tahiu & IIISC & Perkembangan \\
\hline 2010 & 3409 & 34.53 \\
\hline 2011 & 3942 & $1.5,5.4$ \\
\hline 2012 & 4317 & 9,51 \\
\hline 2013 & 4274 & -1.00 \\
\hline 2014 & 5227 & 22,30 \\
\hline 2015 & 4911 & $-6,015$ \\
\hline
\end{tabular}

Dari uraian pada latar belakang di atas, dirumuskan masalah sebagai berikut:

1. Bagaimana pengaruh Inflasi terhadap Indeks Harga Saham Gabungan (IHSG) pada Bursa Efek Indonesia (BEI)?

2. Bagaimana pengaruh Suku Bunga terhadap Indeks Harga Saham Gabungan (IHSG) pada Bursa Efek Indonesia (BEI)?

3. Bagaimana pengaruh Kurs terhadap Indeks Harga Saham Gabungan (IHSG) pada Bursa Efek Indonesia (BEI)?

Tujuan penelitian ini adalah untuk mengidentifikasi dan menganalisis pengaruh :

1. Inflasi terhadap Indeks Harga Saham Gabungan (IHSG) pada Bursa Efek Indonesia (BEI).

2. Suku Bunga terhadap Indeks Harga Saham Gabungan (IHSG) pada Bursa Efek Indonesia (BEI).

3. Kurs terhadap Indeks Harga Saham Gabungan (IHSG) pada Bursa Efek Indonesia (BEI).

Manfaat yang diharapkan dari hasil penelitian ini adalah:

1. Bagi Investor

Sebagai informasi mengenai Pengaruh Inflasi, Suku Bunga SBI, Perubahan Kurs terhadap Indeks Harga Saham Gabungan (IHSG) dan diharapkan dapat bermanfaat sebagai bahan pertimbangan bagi investor dan calon investor dalam memutuskan untuk berinvestasi dengan menggunakan variabel-variabel yang diteliti.

2. Bagi Manajer Investasi

Hasil penelitian ini dapat digunakan sebagai masukan untuk menilai Indeks Harga Saham Gabungan (IHSG).

3. Bagi Akademisi

Penelitian ini diharapkan dapat menjadi rujukan pengembangan ilmu manajemen khususnya keuangan mengenai kajian Indeks Harga Saham Gabungan (IHSG) yang dipengaruhi oleh Inflasi, Suku Bunga SBI, dan Perubahan Kurs.

\section{Inflasi}

Dalam ilmu ekonomi, inflasi adalah suatu proses meningkatnya hargaharga secara umum dan terus-menerus berkaitan dengan mekanisme pasar yang 
dapat disebabkan oleh berbagai faktor, antara lain: konsumsi masyarakat yang meningkat, berlebihnya likuiditas di pasar yang memicu konsumsi atau bahkan spekulasi, sampai termasuk juga akibat adanya ketidak lancaran distribusi barang (Suparmoko, 2009). Dengan kata lain, inflasi juga merupakan proses menurunnya nilai mata uang secara kontinu. Inflasi adalah proses dari suatu peristiwa, bukan tinggi-rendahnya tingkat harga. Artinya, tingkat harga yang dianggap tinggi belum tentu menunjukkan inflasi. Inflasi adalah indikator untuk melihat tingkat perubahan, dan dianggap terjadi jika proses kenaikan harga berlangsung secara terus-menerus dan saling pengaruh-memengaruhi. Istilah inflasi juga digunakan untuk mengartikan peningkatan persediaan uang yang kadangkala dilihat sebagai penyebab meningkatnya harga.

\section{Suku Bunga}

Suku Bunga yang dimaksud adalah suku bunga Sertifikat Bank Indonesia (SBI) yaitu ukuran keuntungan investasi yang dapat diperoleh pemilik modal dan juga merupakan ukuran biaya modal yang harus dikeluarkan oleh perusahaan atas penggunaan dana dari pemilik modal (Suseno, 2008). Bagi investor bunga deposito menguntungkan karena suku bunganya relatif lebih tinggi dibandingkan bentuk simpanan lain, selain itu bunga deposito tanpa resiko (risk free). Kebijakan bunga rendah akan mendorong masyarakat untuk memilih investasi dan konsumsi dari pada menabung, sebaliknya kebijakan meningkatkan suku bunga simpanan akan menyebabkan masyarakat lebih senang menabung daripada melakukan investasi atau konsumsi.

Sertifikat Bank Indonesia (SBI) adalah surat berharga yang dikeluarkan Bank Indonesia sebagai pengakuan utang berjangka waktu pendek (1-3 bulan) dengan sistem diskonto bunga. SBI merupakan salah satu mekanisme yang digunakan Bank Indonesia untuk mengontrol kestabilan nilai Rupiah. Dengan menjual SBI, Bank Indonesia dapat menyerap kelebihan uang primer yang beredar. Tingkat Suku Bunga yang berlaku pada setiap penjualan SBI ditentukan oleh mekanisme pasar berdasarkan sistem lelang. Sejak awal Juli 2005, Bank Indonesia menggunakan mekanisme "BI rate" (Suku Bunga SBI), yaitu mengumumkan target Suku Bunga SBI yang diinginkan Bank Indonesia untuk pelelangan pada masa tertentu. Hal ini kemudian yang digunakan sebagai acuan para pelaku pasar dalam mengikuti pelelangan (BI, 2014).

Dasar hukum penerbitan SBI adalah UU No. 13 Tahun 1968 tentang Bank Sentral,Surat Keputusan Direksi Bank Indonesia No. 31/67/KEP/DIR tanggal 23 Juli 1998 tentang Penerbitan dan Perdagangan Sertifikat Bank Indonesia serta Intervensi Rupiah, dan Peraturan Bank Indonesia Nomor 6/2/PBI/2004 tanggal 16 Februari 2004 tentang Bank Indonesia-Scripless Securities SettlementSystem.

\section{Kurs}

Menurut Thobarry (2009) nilai tukar suatu mata uang asing adalah harga mata uang suatu negara terhadap negara asing lainnya. Nilai tukar atau kurs satu mata uang terhadap mata uang lainnya merupakan bagian dari proses valuta asing. Istilah valuta asing mengacu pada mata uang asing aktual atau berbagai klaim atasnya seperti deposito bank atau surat sanggup bayar yang diperdagangkan. 
Kenaikan harga valuta asing disebut depresiasi atas mata uang dalam negeri. Mata uang asing menjadi lebih mahal, ini berarti nilai relatif mata uang dalam negeri merosot. Turunnya harga valuta asing disebut apresiasi mata uang dalam negeri. Mata uang asing menjadi lebih murah, ini berarti nilai relatif mata uang dalam negeri meningkat. Perubahan nilai tukar valuta asing disebabkan adanya perubahan permintaan dan penawaran dalam bursa valuta asing. Besarnya nilai tukar akan memengaruhi harga barang yang diperdagangkan, sekaligus berpengaruh terhadap besarnya investasi.

\section{Indeks Harga Saham Gabungan (IHSG)}

Bila saham perusahaan telah dicatatkan di bursa efek, maka saham tersebut dengan sendirinya akan menjadi perhatian bagi para pelaku pasar modal, terjadinya transaksi jual beli dan naik turunnya harga akan menyemarakkan kegiatan pasar modal. Berbagai media akan melaksanakan pemantauan terhadap saham tersebut dan juga memuat berita tentang indeks harga yang terjadi. Selain harga saham suatu perusahaan tertentu, hal lain yang menjadi perhatian pelaku pasar modal adalah Indeks Harga Saham Gabungan (IHSG).

IHSG menggambarkan suatu rangkaian informasi historis mengenai pergerakan harga saham gabungan, sampai pada tanggal tertentu. Biasanya pergerakan harga saham tersebut disajikan setiap hari berdasarkan harga penutupan di bursa efek pada hari tersebut. Indeks tersebut disajikan untuk periode tertentu. IHSG mencerminkan suatu nilai yang berfungsi sebagai pengukuran kinerja suatu saham gabungan di bursa efek.

Maksud dari gabungan itu sendiri adalah kinerja saham yang dimasukkan dalam perhitungan lebih dari satu, bahkan seluruh saham yang tercatat di bursa efek tersebut (Sunariyah, 2004 : 142). Indeks Harga Saham Gabungan atau IHSG (CompositeStock Price Index), menggunakan semuasaham yang tercatat sebagai komponen penghitungan indeks. Tanggal 10 Agustus 1982 ditetapkan sebagai hari dasar (nilai Indeks $=100$ ). Perhitungan IHSG adalah sebagai berikut:

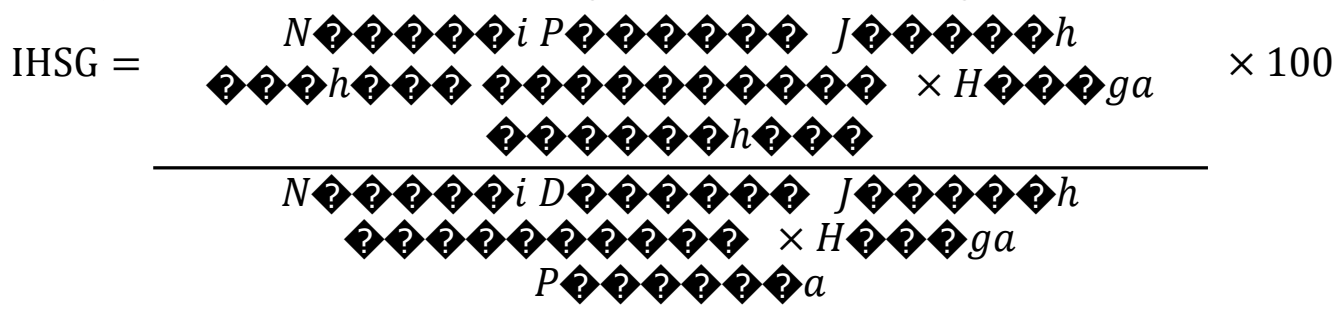

Indeks harga saham setiap hari dihitung menggunakan harga saham terakhir yang terjadi di bursa. Dua macam indeks yang digunakan di Bursa Efek Indonesia adalah Indeks Harga Saham Individual yang mencerminkan perkembangan harga suatu saham dan Indeks Harga Saham Gabungan yang mencerminkan perkembangan pasar secara keseluruhan. Harga saham yang digunakan dalam perhitungan indeks di bursa adalah harga saham yang terjadi di pasar reguler.

Indeks Harga Saham Gabungan (IHSG) pertama sekali diperkenalkan pada tanggal 1 April 1983 sebagai indikator pergerakan harga semua saham yang tercatat di Bursa Efek Indonesia (BEI) baik saham biasa maupun saham preferen. 
Indeks harga adalah suatu angka yang digunakan untuk melihat perubahan mengenai harga dalam waktu dan tempat yang sama atau berlainan. Indeks adalah 
ukuran statistik yang biasanya digunakan untuk menyatakan perubahan-perubahan perbandingan nilai suatu variabel tunggal atau nilai suatu kelompok variabel. Menurut Jogiyanto (2009:174) Indeks Harga Saham Gabungan (IHSG) sebenarnya merupakan angka indeks harga saham yang sudah dihitung dan disusun sehingga menghasilkan trend, di mana angka indeks adalah angka yang diolah sedemikian rupa sehingga dapat digunakan untuk membandingkan kejadian perubahan harga saham dari waktu ke waktu.

Faktor-faktor yang memengaruhi nilai IHSG antara lain indikator ekonomi, harga minyak dunia, kondisi ekonomi global dan kestabilan politik suatu negara. Terdapat pengaruh langsung krisis finansial global terhadap perekonomian di negara Indonesia, yakni pengaruh terhadap keadaan Indeks Bursa Saham Indonesia. Kepemilikan asing yang masih mendominasi dengan porsi $66 \%$ kepemilikan saham di BEI, mengakibatkan bursa saham rentan terhadap keadaan finansial global karena kemampuan finansial para pemilik modal tersebut (Chen, 2012).

Hasil studi yang telah dilakukan oleh beberapa peneliti terdahulu yang relevan dengan penelitian ini yaitu:

Witjaksono (2012) dalam penelitiannya yang berjudul "Analisis Pengaruh Tingkat Suku Bunga SBI, Harga Minyak Dunia, Harga Emas Dunia, Kurs Rupiah, Indeks Nikkei 225, dan Indeks Dow Jones terhadap IHSG (studi kasus pada IHSG di BEI selama periode 2000-2009)" menunjukkan bahwa kurs rupiah berpengaruh negatif terhadap IHSG Setiawan (2012) dalam penelitiannya yang berjudul "Pengaruh Inflasi, Tingkat Suku Bunga, Dan Nilai Tukar Terhadap Indeks Harga Saham Gabungan (IHSG) Di Bursa Efek Indonesia (BEI)" menunjukkan bahwa inflasi berpengaruh positif dan signifikan terhadap IHSG.

Kurniawan (2013) dalam penelitiannya yang berjudul "Analisis Pengaruh Tingkat Suku Bunga SBI, Inflasi, Harga Minyak Dunia, Harga Emas Dunia, Kurs Rupiah Terhadap Dollar Amerika, Indeks Nikkei 225 Dan Indeks Dow Jones Terhadap Indeks Harga Saham Gabungan" menunjukkan bahwa inflasi tidak berpengaruh signifikan terhadap IHSG.

Lestari (2015) dalam penelitiannya yang berjudul "Pengaruh Indeks Dow Jones, Indeks Nikkei 225, Dan BI Rate Terhadap Indeks Harga Saham Gabungan" menunjukkan bahwa BI Rate berpengaruh negatif dan signifikan terhadap IHSG. Taufik (2015) dalam penelitiannya yang berjudul "Pengaruh Inflasi, BI Rate Dan Kurs Terhadap Indeks Harga Saham Gabungan" menunjukkan bahwa inflasi, BI Rate berpengaruh negatif dan signifikan terhadap IHSG sedangkan Kurs berpengaruh positif dan signifikan terhadap IHSG. 


\section{Kerangka Konsep Penelitian}

Kerangka konsep pada penelitian ini dapat dilihat pada gambar berikut:

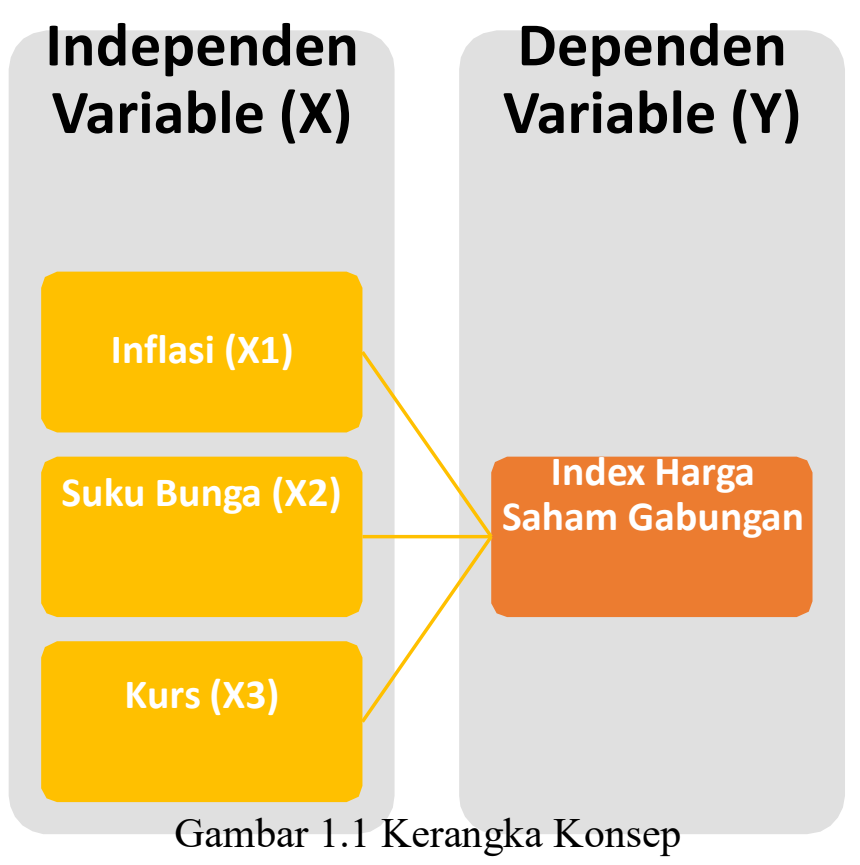

METODE

Penelitian ini menggunakan sumber data sekunder, yang diakses dari webwww.idx.co.id yaitu Indeks Harga Saham Gabungan (IHSG) periode 2010 2015. Populasi dalam penelitian ini adalah seluruh indeks di Bursa Efek Indonesia (BEI). Teknik penentuan sampel menggunakan metode purposive sampling dengan beberapa kriteria yang ditetapkan oleh peneliti, yaitu merupakan: (1) salah satu indeks harga saham di Bursa Efek Indonesia (BEI), (2) indeks harga saham yang mencerminkan harga seluruh saham yang terdaftar di Bursa Efek Indonesia (BEI), (3) Indeks harga saham periode 2010 - 2015.

\section{Populasi dan Sampel}

Populasi yang digunakan dalam penelitian ini adalah data tentang inflasi, Suku Bunga SBI, kurs (Rupiah terhadap dollar AS), sedangkan sampel yang diambil adalah data selama periode 2010-2015 sebanyak 72 bulan yaitu mulai dari bulan Januari 2010 sampai dengan bulan Desember 2015.

\section{Definisi Operasional Variabel}

\section{Inflasi}

Inflasi adalah suatu prosesmeningkatnya harga-harga secara umum dan terusmenerus berkaitan dengan mekanisme pasar yang dapat disebabkan oleh berbagai faktor (Suparmoko, 2009). Inflasi dalam penelitian ini adalah inflasi per bulan yang diukur dengan satuan prosentase $(\%)$. 


\section{Kurs}

Menurut Dahlan Siamat (2007), Kursatau nilai tukar (kurs) adalah harga dalam negeri dari uang luar negeri (asing). Kurs dalam penelitian ini adalah nilai Rupiah terhadap Dollar Amerika per bulan yang diukur dengan satuan Rupiah.

\section{Suku Bunga}

Suku Bunga yang dimaksud adalahsuku bunga Sertifikat Bank Indonesia (SBI) yaitu kebijakan suku bunga yang mencerminkan sikap atau stance kebijakan moneter yang ditetapkan oleh bank Indonesia dan diumumkan kepada publik (Dahlan Siamat, 2007). Suku Bunga SBI dalam penelitian ini adalah inflasi per bulan yang diukur dengan satuan prosentase (\%).

\section{IHSG}

IHSG mencerminkan suatu nilaiyang berfungsi sebagai pengukuran kinerja suatu saham gabungan di bursa efek. Maksud dari gabungan itu sendiri adalah kinerja saham yang dimasukkan dalan perhitungan lebih dari satu, bahkan seluruh saham yang tercatat di bursa efek tersebut (Sunariyah, 2006).

\section{Metode Analisis Data}

1. Uji Kelayakan Model (Goodness of FitTest)

a. Koefisien Determinasi

Koefisien Determinasi $\left(\mathrm{R}^{2}\right)$ pada intinya mengukur seberapa jauh kemampuan model dalam menerangkan variasi variabel dependen.

b. Uji F (F Test)

Uji $F$ digunakan untuk mengetahui apakah variabel bebas berpengaruh secara simultan atau bersama-sama terhadap variabel terikat.

2. Uji Hipotesis (t test)

Uji hipotesis individual yaitu untuk menguji pengaruh secara individual variabel bebas yang terdapat dalam persamaan regresi terhadap nilai variabel terikat.

3. Analisis Regresi Berganda

Analisis Regresi Linier Berganda digunakan untuk mengetahui arah hubungan antara variabel bebas terhadap variabel terikat, apakah masing-masing variabel bebas berhubungan positif atau negatif(Gujarati, 2007:92). Persamaan Regresi Berganda yang digunakan adalah sebagai berikut:

$$
\mathbf{Y}=\mathbf{a}+\mathbf{b} 1 \mathbf{X} 1+\mathbf{b} 2 \mathbf{X} 2+\mathbf{b} 3 \mathbf{X} 3+\mathbf{e}
$$

Dimana :

$\mathrm{Y}=\mathrm{IHSG}$

$\mathrm{a}=$ Konstanta

$\mathrm{b}=$ Koefisien Rehresi Parsial

$\mathrm{X} 1=$ Inflasi

$\mathrm{X} 2=$ Suku Bunga 
X3 $=$ Kurs

$\mathrm{e}=$ Faktor di luar model

\section{HASIL DAN PEMBAHASAN}

\section{Uji kelayakan}

1. Koefisien Determinasi

Koefisien determinasi dilakukan berdasarkan tabel berikut :

Berdasarkan literatur dan pengalaman Empiris, maka dapat dijelaskan hal-hal sebagai berikut :

Tabel 3.1 Koefisien Determinasi

\begin{tabular}{|c|c|c|c|c|}
\hline Model & $\mathrm{R}$ & R. Squas & $\begin{array}{l}\text { Adjusto } \\
\text { l2 } \\
\text { Square }\end{array}$ & $\begin{array}{l}\text { d. Emor of the } \\
\text { Eslinuale }\end{array}$ \\
\hline 1 & $742 a$ & 551 & 536 & 801906 \\
\hline
\end{tabular}

Tabel di atas menunjukkan bahwa nilai Adjusted $R$ Square $=0,536$ yang berarti bahwa kontribusi pengaruh ketiga variabel bebas (inflasi, suku bunga dan kurs) terhadap IHSG sebesar 53,6\% sedangkan yang 46,4\% dipengaruhi faktor lainnya diantaranya kondisi perekonomian, politik dan faktor lainnya.

2. Uji Simultan (Uji F)

Berdasarkan tabel di bawah ini dapat diketahui bahwa nilai $\mathrm{F}$ hitung.

\begin{tabular}{|c|c|c|c|c|c|}
\hline Model & $\begin{array}{l}\text { Sum of } \\
\text { Squares }\end{array}$ & df & $\begin{array}{l}\text { Mean } \\
\text { Square }\end{array}$ & F & Sig. \\
\hline $\begin{array}{c}1 \\
\text { Regression }\end{array}$ & $\begin{array}{c}67945032 \\
30\end{array}$ & 3 & $\begin{array}{c}2264834 \\
4.100\end{array}$ & 35.220 & $.000 a$ \\
\hline Residual & $\begin{array}{c}55302603 . \\
30\end{array}$ & 86 & $\begin{array}{c}643053.5 \\
27\end{array}$ & & \\
\hline Total & $\begin{array}{c}12324763 \\
5.60\end{array}$ & 89 & .000 & & \\
\hline
\end{tabular}

Tabel di atas menunjukkan bahwa nilai $\mathrm{F}$ hitung $=35,220>\mathrm{F}$ tabel $=2,76$ dan angka signifikansi $=0,000<\alpha=0,05$ sehingga signifikan (Ho ditolak dan Ha diterima), artinya berdasarkan hasil uji koefisien dan uji $\mathrm{F}$ di atas dapat disimpulkan bahwa model yang digunakan dalam penelitian ini layak digunakan.

\section{Pengujian Hipothsis}

Pengujian hipotesis dalam penelitian ini dapat dijelaskan berdasarkan tabel di bawah ini. 
Tabel 3.3 Koeflsien Regresi

\begin{tabular}{|c|c|c|c|c|}
\hline \multirow[t]{2}{*}{ Model } & $\begin{array}{c}\text { Unetali } \\
\text { Coeff }\end{array}$ & $\begin{array}{l}\text { darchred } \\
\text { ficients }\end{array}$ & $\begin{array}{l}\text { Standardized } \\
\text { Coefficienti }\end{array}$ & \multirow[t]{2}{*}{ Sig. } \\
\hline & B & Std Enor & Beta & \\
\hline \multirow{3}{*}{$\begin{array}{l}\text { SConstant } \\
\text { Inflass } \\
(\mathrm{x} 1) \\
\text { Susu } \\
\text { Bunga } \\
(\mathrm{X})\end{array}$} & 4808010 & 835112 & 5.757 & 000 \\
\hline & 157214 & 39970 & 3182.622 & 2.010 \\
\hline & -1183942 & 158.159 & -976.7 .496 & 6.000 \\
\hline Kus (X3) & .60 & .071 & 6993517 & .000 \\
\hline
\end{tabular}

1. Pengujian hipotesis pengaruh inflasi terhadap IHSG (H1) Berdasarkan tabel di atas dapat diketahui bahwa nilai $\mathrm{t}$ hitung yaitu 2,622 $>\mathrm{t}$ tabel $=2,000$ dan angka signifikansi $=0,010>\alpha=0,05$ sehingga tidak signifikan (Ho ditolak dan Ha diterima). Dengan demikian hipotesis $\mathrm{H} 1$ yaitu bahwa inflasi berpengaruh terhadap IHSG terbukti.

2. Pengujian hipotesis pengaruh Suku Bunga terhadap IHSG (H2) Nilai t hitung yaitu sebesar $-7,486<\mathrm{t}$ tabel $=-2,000$ dan angka signifikansi $=0,000>\alpha=$ 0,05 sehingga signifikan

3. Pengujian hipotesis pengaruh kurs terhadap IHSG H3) Nilai t hitung yaitu sebesar 8,517 $>\mathrm{t}$ tabel $=2,000$ dan angka signifikansi $=0,000<\alpha=0,05$ sehingga signifikan (Ho ditolak dan Ha diterima). Dengan demikian hipoesis H3 bahwa kurs berpengaruh terhadap IHSG terbukti.

\section{Analisis Regresi Linier Berganda}

Persamaan regresi dalam penelitian ini ialah:

$$
\mathrm{Y}=4808,010+157,214 \mathrm{X} 1-1183.942 \mathrm{X} 2+0,603+\mathrm{e}
$$

Berdasarkan persamaan di atas dapat dilakukan interpretasi sebagai berikut :

1. Koefisien regresi $b 1=157,214$ (signifikan) mempunyai arti bahwakenaikan inflasi sebesar 1\% akan menaikkan IHSG sebesar 157,214 (faktor lain dianggap tetap).

2. Koefisien regresi b2 $=-1183,942$ (signifikan) mempunyai arti bahwakenaikan sebesar $1 \%$ akan menurunkan IHSG sebesar 1183,942(faktor lain dianggap tetap).

Koefisien regresi atau $\mathrm{b} 3=0,603$ (signifikan) mempunyai arti bahwa kenaikan kurs sebesar Rp 1,- akan menaikkan IHSG sebesar 0,603 (faktor lain dianggap tetap). Hasil analisis menunjukkan bahwainflasi berpengaruh negatif (b1 = 157,214)dan signifikan (sig.= 0,010) terhadapIndeks Harga Saham Gabungan (IHSG).Sehingga dapat diinterpretasikan bahwakenaikan inflasi sebesar 1\% akanmenaikkan IHSG sebesar 157,214. Hasilpenelitian ini sesuai dengan hasilpenelitian Taufiq (2015), dalampenelitiannya menunjukkan bahwa inflasiberpengaruh negatif dan signifikanterhadap IHSG dan Setiawan (2012) dalampenelitiannya menunjukkan bahwa inflasiberpengaruh positif dan signifikan 
terhadapIHSG. Namun tidak sesuai dengan hasilpenelitian Kurniawan (2013) yangmenunjukkan bahwa inflasi tidakberpengaruh signifikan terhadap IHSG.

Suku Bunga berpengaruh negatif $(\mathrm{b} 2=-1183,942)$ dan signifikan (sig. = 0,000)terhadap IHSG, sehingga diinterpretasikanbahwa kenaikan sebesar 1\% akan menurunkan IHSG sebesar 1183. Hasilpenelitian ini mendukung penelitian Lestari

(2015) dan Taufiq (2015) yangmenunjukkan bahwa Suku Bungaberpengaruh negatif dan signifikan terhadapIHSG.

Kurs berpengaruh positif (b2 $=0,603)$ dan signifikan (sig.=0,000)terhadap IHSG. Sehingga diinterpretasikanbahwa akan menaikkan IHSG sebesar0,603. Hasil penelitian ini sejalan denganpenelitian Witjaksono (2012), dan Taufiq(2015) yang menunjukkan bahwa Kursberpengaruh negatif terhadap Indeks HargaSaham Gabungan (IHSG).

\section{Kesimpulan}

Berdasarkan data hasil analisis regresilinier berganda dan hasil uji t, diperoleh hasil sebagai berikut:

1. Variabel inflasi, suku bunga, berpengaruh negatif dan signifikan terhadap Indeks Harga Saham Gabungan (IHSG).

2. Sedangkan variabel kurs berpengaruhpositif signifikan terhadap IndeksHarga Saham Gabungan (IHSG).

\section{SARAN}

Saran yang dapat diberikanberdasarkan hasil analisis dalam penelitianini adalah:

1. Para investor perlu memperhatikan fluktuasi inflasi, suku bunga SBI dan kurs Rupiah terhadap Dollar AS. Hal ini harus dilakukan karena hasil analisis membuktikan bahwa ketiga faktor tersebut signifikan memengaruhi Indeks Harga Saham Gabungan (IHSG). Dengan demikian investor akan dapat menghindari kerugian akibat jatuhnya IHSG yang berdampak pada jatuhnya harga saham secara umum dan sebaliknya dapat meraih keuntungan jika dapat memprediksi dampakpositif fluktuasi inflasi, suku bunga SBI dan kurs terhadap IHSG.

2. Untuk peneliti selanjutnya hendaknyadapat lebih menyempurnakan lagidengan menambahkan faktor-faktormakro ekonomi lain yang dapatmemengaruhi IHSG seperti IndeksDow Jones.

\section{Daftar Pustaka}

Amin M. Zuhdi, 2012. Pengaruh TingkatInflasi, Suku bunga SBI,Nilai Kurs Dollar dan Indeks Dow Jones (DJIA)Terhadap Pergerakan IHSG di BEI(Periode 2008-2011). Jurnal FacultyEconomic and Bisnis UniversitasBrawijaya, pp: 1-17.

Chen Nai Fu R.R., 2012. Economic Forcesand the Stock Market. The Journal ofBusiness, 59(3), pp: 383-403.

Dahlan Siamat, 2007. ManajemenLembaga Keuangan. Jakarta: LPFEUI

Gujarati D.N, 2007. Dasar-dasarEkonometrika, Edisi 3, Jilid 2.Terjemahan oleh Julius A. Mulyadi.Jakarta: Erlangga. 
Jogiyanto Hartono, 2009. Teori Portofoliodan Analisis Investasi. Yogyakarta: BPFE- Yogyakarta

Kudal Pallavi, 2010. Impact of MacroEconomic Variable on Indian Stock Market and Strategies for Investor.Tirpude's Journal of BusinessResearch, 4 (1), pp: 39-55.

Kurniawan Yohanes J., 2013. AnalisisPengaruh Tingkat Suku Bunga SBI,Inflasi, Harga minyak dunia, HargaEmas Dunia, Kurs Rupiah TerhadapDollar Amerika, Indeks Nikkei 225dan Indeks Dow Jones Terhadap Indeks Harga Saham Gabungan.Jurnal Ekonomi dan bisnis. Pp: 1-20.

Lestari A.R., 2015. Pengaruh Indeks DowJones, Indeks Nikkei 225, dan Sukubunga SBI Terhadap Indeks HargaSaham Gabungan. Jurnal IlmiahUniversitas Bakrie Vol 3, No. 02.

Manurung Jonni J., dan Adler H., 2009.Ekonomi Keuangan dan KebijakanMoneter. Cetakan Pertama. Jakarta:Salemba Empat.Pratikno Deddy, 2009. Analisis PengaruhNilai Tukar Rupiah, Inflasi, SBI DanIndeks Dow Jones TerhadapPergerakan IHSG di BEI. JurnalEconomic Universitas SumateraUtara Medan, pp: 16-99.

Raharjo Sugeng, 2010. Pengaruh Inflasi,Nilai Kurs Rupiah Dan Tingkat SukuBunga Terhadap Harga Saham diBEI. Jurnal Ekonomi Surakarta. pp:1-16.

Rismawati, 2013. Pengaruh PertumbuhanAset, Tingkat Suku Bunga SBITerhadap Kebijakan Deviden DanNilai Perusahaan di BEI. SkripsiSarjana Jurusan ManajemenKeuangan Fakultas Ekonomi danBisnis Universitas Udayana, Bali.

Setiawan Aditya, 2012. Pengaruh Inflasi,Tingkat Suku Bunga, Dan NilaiTukar Terhadap Indeks Harga SahamGabungan (IHSG) Di Bursa EfekIndonesia (BEI). Jurnal: STIEDharmaputra Semarang.

Sunariyah, 2006. Pengantar PengetahuanPasar Modal. Yogyakarta: UPP StimYKPN.

Suparmoko M., 2009. Ekonomi PublikUntuk Keuangan dan PembangunanDaerah. Yogyakarta, Penerbit: Andi.Suseno Astiyah S., 2008. Inflasi. Jakarta:Bank Indonesia.

Tandelilin Eduardus. 2010. Portofolio danInvestasi Teori dan Aplikasi.Yogyakarta: Kanisius.Taufiq M. \& Kefi B. S., 2015. PengaruhInflasi, BI Rate dan Kurs TerhadapIndeks Harga Saham Gabungan.Jurnal Dosen STIE DharmaputraSemarang 2015.

Thobarry Achmad Ath. (2009). AnalisisPengaruh Nilai Tukar, Suku Bunga,Laju Inflasi Dan Pertumbuhan GDPTerhadap Indeks Harga SahamSektor Properti (Kajian Empiris PadaBursa Efek Indonesia PeriodePengamatan Tahun 2000-2008).Tesis. Universitas Diponegoro,Semarang. 